\title{
Isolated right subclavian artery with atrioventricular septal defect: a rare association
}

\author{
Manish Shaw, Arun Sharma, Rengarajan Rajagopal, Sanjeev Kumar
}

Cardiovascular Radiology \& Endovascular Interventions, All India Institute of Medical Sciences, New Delhi, India

\section{Correspondence to} Dr Sanjeev Kumar, sanjeevradio@gmail.com

Accepted 22 July 2019
A) Check for updates

(c) BMJ Publishing Group Limited 2019. No commercial re-use. See rights and permissions. Published by BMJ.

To cite: Shaw M, Sharma $A$, Rajagopal R, et al. BMJ Case Rep 2019;12:e231790. doi:10.1136/bcr-2019231790

\section{DESCRIPTION}

Review of CT angiography (CTA) images from a 6-year-old male cyanotic child with an echocardiographic diagnosis of transposition of great arteries, atrioventricular septal defect (AVSD) and pulmonary stenosis, showed left sided aortic arch with complete isolation of right subclavian artery (RSCA). Aortic arch branching pattern was as follows: right common carotid artery followed by left common carotid artery and left subclavian artery (LSCA). RSCA was seen to be connected to good sized right pulmonary artery via a patent ductus arteriosus with distal luminal narrowing (figure 1). Right limb was not hypoplastic as compared with left and there were no cerebral symptoms. Coronaries were arising from separate pulmonary facing aortic sinuses with multiple significant aortopulmonary collaterals from descending thoracic aorta. Colour Doppler revealed reversal of flow in right vertebral artery with low velocity monophasic flow in RSCA (figure 2).

Isolation of RSCA arises due to developmental defect where the dissolution of right fourth aortic arch and right dorsal aorta occurs with persistence of distal right sixth arch. This leads to formation of right sided ductus and pulmonary artery connected to RSCA. ${ }^{1}$ Isolation of LSCA is four times more common than right and is often associated with conotruncal anomalies. ${ }^{2}$ Association of AVSD with isolated LSCA has been previously reported. ${ }^{3}$ However, to the best of our knowledge, association of AVSD with isolated RSCA has not been previously reported. CTA, being

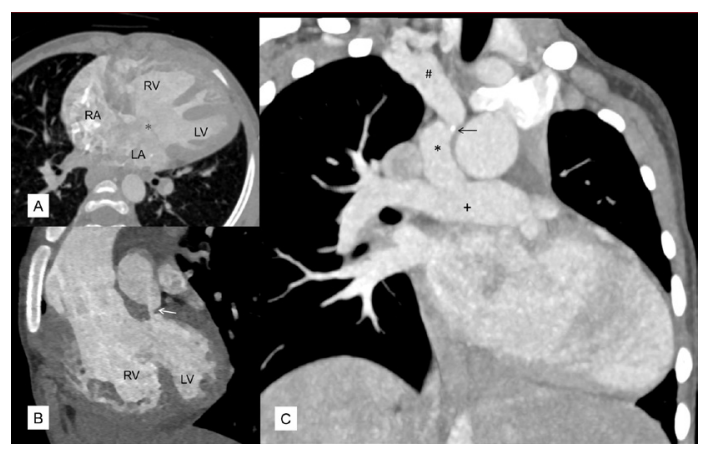

Figure $1 \mathrm{CT}$ angiography showing (A) atrioventricular septal defect $\left({ }^{*}\right)$ noted in the 4-chamber image, (B) aorta arising from anteriorly placed right ventricle (RV) and pulmonary artery from left ventricle (LV) along with tight infundibular pulmonary stenosis (white arrow). (C) There is isolation of right subclavian artery (\#) connected via patent ductus arteriosus $\left({ }^{*}\right)$ to right pulmonary artery $(+)$ in coronal maximum intensity projection (MIP) image, along with a calcific speck (black arrow). LA, left atrium; $\mathrm{RA}$, right atrium.

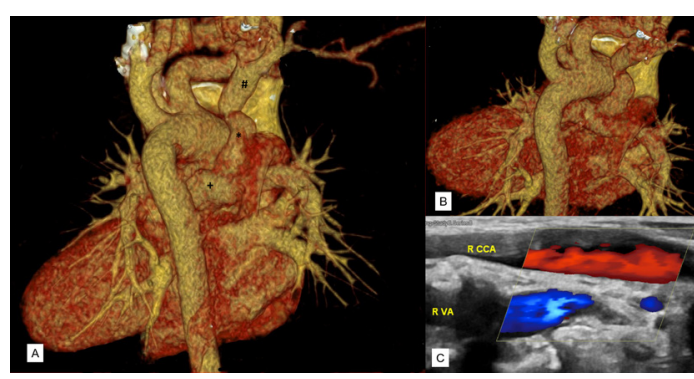

Figure 2 Virtual reconstructed tomography (VRT) image (as seen from posterior aspect of body) reveals the spatial orientation of isolated right subclavian artery (\#) connected via patent ductus arteriosus $\left({ }^{*}\right)$ to right pulmonary artery (+) and aortic arch branches (A and B). Colour Doppler (C) showing the reverse flow in right vertebral artery (blue colour) as compared with right carotid artery (red colour).

a non-invasive investigation can accurately diagnose aortic arch pathologies with simultaneous assessment of associated cardiac defects, lung parenchyma and coronaries which may have therapeutic implications. Surgical division and reimplantation along with repair of associated defects remains the procedure of choice in cases of isolated subclavian artery.

\section{Learning points}

- Isolation of the subclavian artery is a rare aortic arch anomaly usually seen in association with congenital heart defects.

- Vertebrobasilar insufficiency due to subclavian or pulmonary steal, decreased limb growth or limb claudication may be early clues to this rare diagnosis.

Contributors MS, AS, RR and SK Contributed equally.

Funding The authors have not declared a specific grant for this research from any funding agency in the public, commercial or not-for-profit sectors.

Competing interests None declared.

Patient consent for publication Parental/guardian consent obtained.

Provenance and peer review Not commissioned; externally peer reviewed.

\section{REFERENCES}

1 Konstantinov IE, Saxena P, d'Udekem Y, et al. Isolated subclavian artery: anatomical and surgical considerations. Ann Thorac Surg 2009;88:1685-7.

2 Sen S, Mohanty S, Kulkarni S, et al. Isolated subclavian artery: a rare entity revisited. World J Pediatr Congenit Heart Surg 2016;7:744-9.

3 Roy A, Kothari SS, Singh $\mathrm{H}$, et al. Isolation of the left subclavian artery. Indian Heart J 2003;55:65-7. 


\section{Images in...}

Copyright 2019 BMJ Publishing Group. All rights reserved. For permission to reuse any of this content visit https://www.bmj.com/company/products-services/rights-and-licensing/permissions/

BMJ Case Report Fellows may re-use this article for personal use and teaching without any further permission.

Become a Fellow of BMJ Case Reports today and you can:

- Submit as many cases as you like

- Enjoy fast sympathetic peer review and rapid publication of accepted articles

Access all the published articles

Re-use any of the published material for personal use and teaching without further permission

Customer Service

If you have any further queries about your subscription, please contact our customer services team on +44 (0) 2071111105 or via email at support@bmj.com.

Visit casereports.bmj.com for more articles like this and to become a Fellow 